\title{
Reading
}

\section{Aquinas in the}

\section{Renaissance:}

\section{Dominic of}

Flanders on the

\section{Imagination}

\section{and Phantasm}

\section{BRIAN GARCIA}

Hoger Instituut voor Wijsbegeerte, KU Leuven Kardinaal Mercierplein 2, 3000 Leuven, Belgie

Brian.Garcia@hiw.kuleuven.be

\section{ABSTRACT}

This paper takes up the $15^{\text {th }}$ century thinker, Dominic of Flanders, as a reader of Thomas Aquinas and indeed a representative of Renaissance Thomism. The topic at hand is Dominic's presentation of phantasia, or imagination, and the phantasma. The phantasm, of course, plays a prominent role in the Aristotelian model of intellectual cognition, yet seems to remain a somewhat vague concept. We will show some of Dominic's peculiar characterizations of the phantasm. In the background of our analysis is a broader reflection concerning methodology. It is suggested that in order to judge better Dominic as a reader of Thomas, a static understanding of the latter must be avoided, and rather that his doctrine be problematized. By drawing attention to certain ambiguities in Thomas' characterizations of the phantasm and the role of the imagination, we can better situate Dominic's interpretation.* 


\section{INTRODUCTION}

In the third book of his De Anima, Aristotle announces his famous and influential dictum that there is no thinking without phantasms. ${ }^{1}$ In this paper, I would like to draw attention to the ontological status of the phantasm, since it seems to be a question that often goes unasked in the various contexts wherein the notion of the phantasm arises in the commentary tradition. In contemporary discussions-employing very broad strokes here-problems concerning the theme of the phantasm (or, better to say problems concerning the 'imagination' more broadly construed) are consigned to topics relating specifically to epistemological matters, or within the frames of discourse typical to the philosophy of mind. This evaluation holds good for those contemporary trends of Aristotelian or Thomistic philosophy that take up the theories of intellect or knowledge as they are found in either Aristotle or Thomas-trends which have been recognized as 'analytic' in their methods. That there might be a problem concerning the understanding of the phantasm within such treatments is brushed over by the common translation of phantasma variously as 'image,"sensible-image," mentalimage,' and the like. For the most part, these remarks are of course with specific consideration to the English-speaking analytic literature; however, some similar trends in European treatments of these topics should not be regarded as immune to such difficulties, treatments which attempt to uncover, e.g., theories 
of intentionality in the Middle Ages, or argue whether or not Thomas puts forth a 'representational' account of intellectual cognition. Further, a lingering difficulty lies in the task of thinking as the medievals did, that is, thinking our way back into a framework of Aristotelian physics in order not to impose the commonplace modern habits of mind-body dualism. Such a rigid dualism might present difficulties in understanding medieval conceptions of materiality and immateriality, corporeality and spirituality. Notable scholars have gone so far as to question, in discussions concerning Thomas on the imagination, whether a phantasm is really necessary for 'higher orders' of understanding. ${ }^{1}$ We do not intend to enter into the discussions of specific contemporary variations of a theme here; we simply indicate that these topics indeed continue to give rise to debate.

Despite this contemporary discourse, which may or may not engage in a kind of anachronistic engagement with Thomas and other thinkers, earlier in the $20^{\text {th }}$ century we find more nuanced treatments concerning the relation between the sensitive and intellective part of the soul, the reliance upon the phantasm, and the account of the imagination within the medieval classifications of the internal senses. On the Neo-scholastic, Thomistic front, we can point to Cornelio Fabro, who will offer a more sympathetic account of the apparent problem concerning the cogitative power; Fabro claims

1 For example, see Frede 2001. that the intellect is able to overflow and impregnate the higher sensitive powers-namely, the cogitativa-with a share of reason. ${ }^{2}$ Further, Bernard Lonergan insists upon the 'insight into phantasm,' and goes so far as to claim that the phantasm is the object of the intellect-indeed, the proper object of the intellect in its embodied state. ${ }^{3}$ Here we only signal a thinker of the $20^{\text {th }}$ century, careful reader of Thomas as he was, who perceived the great importance of the phantasm in human understanding.

In the Middle Ages and in the Renaissance, the theme of the imagination and phantasm arose in very different contexts. It is perhaps anachronistic to treat thinkers from these periods as putting forth a 'philosophy of mind' or even an 'epistemology,' abstracted as it were from their fertile ground of discourse in order to meet the needs of our philosophical concerns as well as our terminology. Or, at least such an analysis must be carefully carried out. In the first place, such discussions occurred almost always within the commentary-tradition of scholasticism, taking the Aristotelian framework as the ambit within which debate and variation took place-and such a context implied also the question of the correct understanding or interpretation of Aristotle himself. The problem of the necessity of the phantasm arose

\footnotetext{
2 For example, see Fabro 1938.

3 Lonergan 1997; see, eg., "Insight into Phantasm," pp. 38-46. Also, Lonergan 1992; the epigraph that prefaces the entire work is Aristotle, De anima III, 431b2.
} 
not simply in matters related to the problem of knowledge-and here I do not intend to mean that it did not arise in this context-but rather within the broader discussions concerning the soul's relation to body, the unity or multiplicity of the intellect, the state of the soul after death, and consequently, the immortality of the soul. These topics, of course, have bearings upon spheres theological. Perhaps a clear sign of this is Pietro Pomponazzi's discussion in De Immortalitate Animae, ${ }^{1}$ in which the necessity of the phantasm plays an integral role throughout; we can also point to Marsilio Ficino's refutation of the Averroistic position in his Theologia Platonica. $^{2}$

These prefatory remarks so far attempt to place the theme of this paper within what might be competing philosophical and historical trends that take up these seemingly familiar problems in the Aristotelian-Thomistic tradition: namely-and working backwards from the way they have just been presented-(1) the commentary tradition of the Middle Ages and Renaissance, (2) the $20^{\text {th }}$ century impetus of Neo-scholasticism, and then (3) the more or less contemporary, 'analytic' bend typical of Aristotle and Thomas studies. I would like to turn now to our problem as we find it in the Middle Ages and Renaissance, namely, in the writings of the renowned theologian Thomas Aquinas-indeed, an authority for the subsequent generations-and

1 See the discussion of the intellective soul and imagination already in: Pomponazzi 1948, p. 286ff (ch. 4).

2 E.g., Ficino 2005, p. $109 f f$ (bk. 15, ch. 10). then Dominic of Flanders, a Dominican philosopher only scantily known.

First, we will offer a very brief sketch of what might be a conventional 'Thomistic' account of the imagination. After this, we will then problematize the issue of phantasm in Thomas, by drawing special attention to possible problems or contradictions that might arise in trying to determine the ontological status of the phantasm in his writings. This step is necessary on a methodological level in order to evaluate better our findings concerning the treatment put forth by Dominic of Flanders. Dominic of Flanders $(+1479)$ was a product of both mid- $15^{\text {th }}$ century University of Paris as well as the Dominican studium at Bologna. He was a prominent Thomist during his own lifetime, and well-known as such at least into the $17^{\text {th }}$ century. In order to evaluate Dominic and our findings concerning what he has to say about the internal senses, the intellective soul, and the very workings of the intellectall matters that somehow shed light on the phantasm-it is perhaps best not to judge such a figure against a static and definitive understanding of Thomas' own articulations, since such an understanding might without notice rely upon some Neo-scholastic projections of the $20^{\text {th }}$ century, or upon those tendencies I have pointed out above typical of the contemporary treatments of Thomas. So, this current paper has no hopes to offer a coherent and complete account of Thomas, but rather will try to problematize his theory of the phantasm in order to see the 
possible pieces with which Dominic will offer his own reading of Thomas, and whether his understanding contains any novelty or innovation. Dominic was no humanist; rather, he was a rigorous scholastic working in the tradition of his esteemed confrère. As such, the task of identifying and ranking novelty in his thinking is not without difficulty, and for this reason we must attempt to press upon potential problems within Thomas' own articulations.

\section{- 2 AQUINAS ON PHANTASIA AND PHANTASMA}

Firstly, for Thomas, as for many of the medievals, phantasia is found within an elaboration of the internal senses. The internal senses are posited as potencies distinct from the proper external senses. Thomas posits a fourfold classification of the internal senses: viz., the common sense, phantasia, an estimative power, and memory. (The numeration of the interior senses will vary throughout the Middle Ages: Avicenna, for example, famously posits five internal senses; Averroes proposes a fourfold model; while Henry of Ghent posits only three.) The common sense, for Thomas, is both the root and terminus of sensitivity as such, and also of each individual proper sense. It is by the common sense that we have a kind of primitive unified appearance of things, such that the proper objects of sense are not confused with one another-at least in the case of those with proper functioning organs. Phantasia is posited as that which is retentive of the sensible forms apprehended in sensation; so, sensible forms are stored by phantasia, which is also called a treasury of sensible forms. In the ST Ia, q. 78, Thomas indicates that phantasia and imaginatio are synonymous. Next is the estimative power, which apprehends intentions that are not properly sensed. By these 'un-sensed' intentions of convenience or harm, the typical example given is of a sheep perceiving the wolf as an enemy-these intentions are not sensed through the external senses per se, but are nonetheless received, and cannot be said to be understood in a rational way, in the case of brute animals. In man, the estimative power is elevated and is called the cogitative power, or alternatively, the particular reason. Memory is posited as the storehouse precisely for these intentions that are not grasped by the external senses.

Here, for our current purposes, we will follow the lead of Norman Kretzmann in order to give a brief and comprehensive picture of the entire process of cognition. Bodily things existing in the world make impressions upon the external senseorgans; the impressions give rise to the sensible species in the receiver, which are given over to the internal senses, where then they are either stored or somehow prepared or processed. Here, it is phantasia that preserves and/ or produces the sensory data that, we will learn, are indispensable for the operation of the intellect-namely, the phantasms. Phantasms thus are essentially sense-data. Aquinas distinguishes between two intellective 
powers: the agent intellect, which acts on the phantasms in a way that produces the intelligible species-these intelligible species are the primary contents of the mind-and these then are stored in the possible intellect. It is through a process of abstraction that the intellect is able to grasp the universal represented in the phantasm. We have here moved from external sensation to intellection. Kretzmann offers this further description of the phantasm: "Phantasms are likenesses of particular material things re-realized in physical configurations of the organ of phantasia, which Aquinas located in the brain. Although the forms presented in phantasms have been stripped of their original matter, the phantasm-likeness is particularized by its details, the external object's original individuating matter being 'represented' by features of the phantasm. Phantasms themselves, then, are not proper objects of intellective cognition, although they are indispensable to it." internal senses, whose proper function is to store the sensible species received from sensation; phantasms are either themselves received from sensation or produced by phantasia; phantasms are likenesses of particular material things, and the intellect needs phantasms both to abstract intelligible species from phantasms, and, reversely, to consider the natures of things universally in the phantasms. Let this suffice for our conventional sketch.

\section{PROBLEMATIZING THE}

\section{PHANTASM IN THOMAS AQUINAS}

Now, let us problematize these themes in Thomas, by surveying a catalogue of meanings attached first to phantasia, and then to the phantasma. The problems running in the background here are: (1) whether phantasm is an object of phantasia (either as received, or somehow produced by phantasia), or whether the phantasm might be an object of the intellect; (2) more generally, whether the phantasm is something material or spiritual. What would it mean to say that a phantasm is a likeness of a particular material thing stripped of its matter, and then maintain that the phantasm is nonetheless material, so far as it exists in the organs of sensation? Surely it must have a spiritual or intentional mode of existence. If we skip ahead to such a thinker as Francisco Suárez, we find that he repeatedly characterizes the phantasm as material (phantasma autem materiale est), and indeed often employs the term 'material phantasm' (phantasma materialis) precisely in his rejections of Thomas and the Thomists. ${ }^{2}$ So, we would be right to wonder whether a Thomist such as Dominic might have understood Thomas to have conceived of such a material phantasm.

2 Suárez 1861. See, for example, lib. 4 cap. 2 (utrum ad productionem specierum intelligibilium admittere oporteat intellectum agentem): "nam intellectus non movetur nisi ab objecto interius in phantasmate repraesentato, phantasma autem materiale est" (p. 716); “[...] nam ipsum materiale est, lumen autem intellectus agentis est spirituale: non poterat ergo formaliter inhaerere materiali phantasmati" (p. 717). 
Regarding phantasia, here are six characterizations or descriptions in Thomas' writings:

1: The particular senses and the common sense are for the reception of sensible forms. Phantasia, then, is directed at the retention and preservation of sensible forms: phantasia is a sort of store-house for (sensible) forms grasped through the (external) senses. Phantasia is synonymous with imagination. ${ }^{1}$

2: Phantasia is a certain movement of the sensitive part, caused by the senses in their act of sensing, and cannot exist without sensation. This

"Sic ergo ad receptionem formarum sensibilium ordinatur sensus proprius et communis [...] ad harum autem formarum retentionem aut conservationem ordinatur phantasia, sive imaginatio, quae idemsunt: est enim phantasia sive imaginatio quasi thesaurus quidam formarum per sensum acceptarum" (ST la 78,4 c. [256]). All text from Thomas Aquinas will be taken from the Leonine Editions, using the standard abbreviations in the citation of questions and articles, or books and chapters; specific page numbers are given in brackets. Text from the Summa is from: Opera omnia, vol. 5: Pars Prima Summae Theologiae, a quaestione $L$ ad quaestionem CXIX (Romae ex Typographia Polyglotta, 1889). Text from Thomas' De Anima commentary is taken from: Opera omnia, vol. 45,1: Sententia libri de Anima (Roma: Commissio Leonina, 1984). When referring to this text, we will also provide the older division of the commentary as it is found in, e.g, the Marietti edition, when there is a discrepancy between Books 2 and 3, for the convenience of the reader: In Aristotelis Librum de Anima Commentarium, $5^{\text {th }}$ ed., ed. by A. M. Pirotta (Torino: Marietti, 1959). We should note that Dominic's reference to Thomas' De Anima commentary naturally follows the older division into lectiones, thus the inclusion of the alternative citations proves helpful. movement produced by sensation must somehow resemble sensation (following the principle that every agent causes something similar to itself-omne agens agit sibi simile). ${ }^{2}$ This of course is Aristotle's classic definition of phantasia from the De Anima.

3: Phantasia is a kind of appearance or capacity for appearance, in which things appear both to sense and intellect in the absence of sensible objects. It is important to stress here that phantasia seems to have its own operation. We infer that phantasia is a capacity (potentia) that has its own operation distinct from both sense and intellect. ${ }^{3}$

4: Phantasia is in our power, and somehow has the capacity to form apparitions (idola) at will (for example, we can freely produce an image of golden mountains as if before our eyes). ${ }^{4}$ This

"phantasia autem nihil aliud est quam motus factus a sensu secundum actum" (Sent. de Anima II, cap. 4); “ex quo etiam manifestum est quod motus causatus ab actu sensus necesse est quod sit similis sensui, quia omne agens agit simile sibi [...] phantasia sit quidam motus causatus a sensu secundum actum, qui quidem motus non est sine sensu neque potest inesse hiis quae non sentiunt" (Sent. de Anima [Leon.] II, cap. 30; [Mar.] lib. III, lect. 6).

3 “nam phantasia apparitio quaedam est: apparet autem aliquid et secundum sensum et secundum rationem. Phantasia etiam habet suam operationem in absentia sensibilium, ut ratio et intellectus" (Sent. de Anima [Leon.] III, cap. 10; [Mar.] lib. III, lect. 16).

4 "passio phantasiae est in nobis cum volumus, quia in potestate nostra est formare aliquid, quasi apparens ante oculos nostros, ut montes aureos vel quicquid volumus, sicut patet de illis qui recordantur et formant sibi idola eorum quae sibi videntur ad votum" (Sent. de Anima [Leon.] II, cap. 28; [Mar.] lib. III, 
is interesting, since it already departs from the characterization of phantasia as simply retentive of sensible forms received from external sensation. This phantasia is something in our power, and has more in common with what might be our common and colloquial conception of phantasia precisely as fantasy.

5: Again, following Aristotle, the senses cannot err concerning their proper objects; falsity and error are thus somehow proper to phantasia. ${ }^{1}$

6: This last characterization will not be pressed upon in this study, but we nonetheless mention that phantasia is intimately connected with the appetite, insofar as the appetite is moved by the images of the phantasia. ${ }^{2}$

Phantasia, once we isolate these aspects as objects of our attention, is quite elusive. It has a passive character insofar as it is a 'store-house' for sensible forms, while somehow providing us with the independent capacity to conjure up apparitions (that is, it is in our power); it originates from sensation (and is related to the appetite), but also somehow allows for the occasion of error. It should be noted that only the first description was taken from the Summa Theologiae; the cases that exhibit a more active lect. 4).

1 “falsitas non est propria sensui, sed phantasiae" (Sent. de Anima [Leon.] II, cap. 29; [Mar.] lib. III, lect. 5).

2 "et quod dicitur de intellectu, intelligendum est etiam de phantasia; quia cum phantasia movet, non movet sine appetitu. Non enim movet, nisi inquantum repraesentat appetibile, sicut nec intellectus" (Sent. de Anima [Leon.] III, cap. 9; [Mar.] lib. III, lect. 15). character of phantasia were taken from the Sent. de Anima. At the very least, perhaps Thomas presents a concise treatment in his $S T I a$, q. 78, while he is willing to go into more detailed consideration of phantasia as it arises in Aristotle's own text. It seems there might be two different interpretations or uses of phantasia in Aquinas: one simply passive and retentive, the other having a more complicated operation which is sometimes in our power.

Now, we move to look at a brief inventory of the uses of phantasma:

1: The phantasm is a likeness (similitudo) of a particular thing. ${ }^{3}$ This is probably the best known 'definition' of the phantasm.

2: The agent intellect, a higher and more noble capacity, makes the phantasms received from the senses actually intelligible by a process of abstraction. ${ }^{4}$ This is a rare moment where Thomas actually says, explicitly, that phantasms are received from the senses.

3: Just as someone who is sensing is moved by sensible objects, so too is one phantasizing moved by these appearances which are called phantasms. $^{5}$ This is a curious and

3 “ipsum phantasma est similitudo rei particularis" (ST la 84,7 ad. 2 [325]); "phantasmata, cum sint similitudines individuorum" (ST Ia 85,1 ad. 3 [332]).

4 "sed illud superius et nobilius agens quod vocat intellectum agentem, de quo jam supra diximus, facit phantasmata a sensibus accepta intelligibilia in actu, per modum abstractionis cuiusdam" (ST la 84,6 c. [324]).

5 "sicut enim sentiens movetur sensibilibus, ita in phantasiando movetur a quibus apparentibus, quae dicuntur 
telling passage. The translation of phantasiando as simply 'imagining' or 'imaging' ought to be avoided. This use of phantasiando furnishes some support to the idea that phantasm is related to phantasia as object, and thus this phantasizing would then be the correlative act.

4: Phantasms are to the intellect just as colors are to sight: just as the species of color are in sight, species of phantasms are in the possible intellect. ${ }^{1}$ This is an important analogy, and will come up in Dominic's treatment, but here, we are perfectly right to infer the conclusion that the phantasms stand to the possible intellect as objects, indeed, proper objects.

5: It is impossible for our intellect (in its current embodied state) actually to understand without turning towards phantasms. $^{2}$ This is the famous Aristotelian phantasm-dictum.

6: Phantasms have a relation to the intellective part of the soul just as sensible objects have a relation to sense. Hence, just as sense is moved by sensibles, so too is intellect moved by phantasms. Just as sense is not able to complete its act of sensation

phantasmata" (Sent. de Anima [Leon.] II, cap. 30; [Mar.] lib. III, lect. 6).

"Sic enim se habent phantasmata ad intellectum, ut dicitur in III de Anima, sicut colores ad visum. Sicut ergo species colorum sunt in visu, ita species phantasmatum sunt in intellectu possibili" (ST la 76,1 c. [209]). bile est intellectum nostrum, secundum praesentis vitae statum, quo passibili corpori coniungitur, aliquid intelligere in actu, nisi convertendo se ad phantasmata" (ST la 84,7 c. [325]).

without the sensible objects, so too is the soul not able to understand without phantasms. The intellect is the terminus of all phantasms ${ }^{3}$-this final point is worth emphasizing.

To sum up: a phantasm is a likeness of a particular material thing; it is apparently received from sensation; it moves the perceiver just as sensible objects move sensation; the phantasm is necessary for actual intellectual understanding; phantasms seem to be the objects of the intellect, and phantasms have their term in the intellect. It is our hope that, at least superficially, these brief inventories reveal some possible problems or challenges for a coherent interpretation.

\section{DOMINIC OF FLANDERS ON}

\section{THE INTERNAL SENSES}

Concerning the recent attention given to Dominic (that is to say, scholarship in the last century), his short commentary on Aristotle's De Anima has been rather neglected. This work takes the form of a super-commentary insofar as it is an exegesis or summary of Thomas' own commentary on Aristotle's great work in natural philosophy. Dominic's Expositio

"Dicit ergo primo, quod phantasmata se habent ad intellectivam partem animae, sicut sensibilia ad sensum. Unde sicut sensus movetur a sensibilibus, ita intellectus a phantasmatibus. [...] quod si phantasmata se habent ad animam intellectivam sicut sensibile ad sensum; sicut sensus non potest sentire sine sensibilie, ita anima non potest intelligere sine phantasmate [...] intellectus est terminus omnium phantasmatum" (Sent. de Anima [Leon.] III, cap. 6; [Mar.] lib. III, lect. 12) 
super libros De Anima ${ }^{1}$ enjoyed a wide circulation, owing to its being appended to many printed editions of Thomas' own commentary of the work, as a kind of compendium. ${ }^{2}$

Let us first look at a complete elaboration of the internal senses found in the commentary:

"It must be said that besides the exterior senses, four interior senses are posited, which are the common sense, the imaginative power (which is called phantasia in brute animals), the estimative power (which is called the cogitative power, or particular reason, in man), and memory. Regarding these matters a sufficient account may be put forth: for sense is perceptive of sensible objects, thus it is either perceptive of the species of sensed things or of the intentions of those things that are not perceived by the exterior senses. If the first, this then is twofold: either (1)

There are four surviving manuscripts of this work: see Kaeppeli 1970, p. 317. For the purposes of this paper, we will cite from the following edition: Divi Thomae Aquinatis in tres libros de Anima [...] Accedunt adhaec acustissime Quaestiones Magistri Dominici de Flandria [...] (Venetiis: Hieronymum Scotum, 1550); henceforth, we will cite as De Flandria, De Anima, followed by book, treatise, chapter, and then folio and column. This edition is readily available through some online resources, such as the SIEPM virtual library for Medieval Philosophy: <capricorn.bc.edu/ siepm/books.html>. I do not necessarily respect the punctuation of this edition; some very minor corrections to the text have been introduced; a more detailed study of Dominic's commentary, taking into account the manuscripts, is underway by the present author.

2 Gauthier 1984, p. $19^{*}-28^{*}, 34^{*}$ in Aquinas, Sent. de Anima. such a sense is ordered to receive those sensible species, and this is the common sense; or (2) a sense is ordered to retain and preserve those species, and this is the imaginative power, which is called a treasury of the species of sensed things. If the second, this then is twofold: either (3) that sense is ordered for the receiving of such intentions, and this is the estimative power in brute animals, and the cogitative power, or particular reason, in man; or (4) it is ordered to retain and preserve those intentions, and this is the sensitive memory. And while to receive and to retain does not pertain to diverse potencies in spiritual beings, in corporeal beings, however, to receive belongs to one kind of potency and to retain belongs to another. For we see that that which receives well contains poorly, and that which receives poorly retains well."3

“Dicendum quod praeter sensus exteriores ponuntur quatuor sensus interiores qui sunt sensus communis, vis imaginativa, quae dicitur phantasia in brutis, et aestimativa, quae dicitur vis cogitativa, vel ratio particularis in homine, et memoria. Quorum sic potest formari sufficientia. Nam sensus est perceptivus sensibilium, aut ergo est perceptivus specierum sensatarum aut intentionum quae non percipiuntur a sensu exteriori. Si primum, hoc est dupliciter, aut talis sensus ordinatur ad accipiendum illas species, et sic est sensus communis, vel ad retinendum et conservandum eas, et sic est vis imaginativa, quae dicitur thesaurus specierum sensatarum. Si secundum, hoc est dupliciter, vel ordinatur ad recipiendum illas intentiones, et sic est aestimativa in brutis, et cogitativa sive ratio particularis in hominibus, vel ordinatur ad retinendum et conservandum illas intentiones, et sic est memoria sensitiva. Et licet accipere et retinere in spiritualibus non pertineant ad diversas potentias, tamen in corporalibus ad 
Concerning the classification of the internal senses, Dominic follows Thomas in his four-fold elaboration. The above-passage is both concise and clear, and is reminiscent of Thomas' treatment in the Summa (Ia 78.4). The only small detail to note here is that Dominic explicitly claims that the imaginative power is called 'phantasia' in brute animals. This is a distinction that Thomas does not explicitly make, however, gives support to the interpretation that Thomas gives the term 'imagination' (or, the 'imaginative power') a wider range of operation than phantasia proper, which retains the sensible species, at least with respect to man. Dominic does not observe this distinction later, towards the end of the third book of the De Anima, when he claims that phantasia can be understood two ways. Earlier, in Book II, he had divided phantasia into indeterminate and determinate phantasia, belonging in the former instances to imperfect animals, and the latter to perfect animals. ${ }^{1}$ Later in Book III, determinate phantasia is further divided into sensible determinate phantasia, which is without deliberation, and rational determinate phantasia, which provides for a kind of discursive deliberation, and is found only in man. Also in Book III, Dominic indicates that phantasia can

aliam potentiam pertinet recipere, et ad aliam retinere. Videmus enim quod illae quae bene recipiunt male retinent, et illae quae male recipiunt bene retinent," De Flandria, De Anima III, tr. 1, cap. 3, 79r, col. 1-2 (emphases in the translation, naturally, are my own).

1 See, e.g., De Flandria, De Anima II, tr. 1, cap. 4,69 r, col. 1. be taken as properly and in itself, and distinguished against the intellective part; however, it can also be taken so far as it extends to the understanding, insofar as phantasible matter (materia phantasialis) is called intelligible matter (materia intelligibilis). Here of course, Dominic is trying to resolve the matter at hand as it appears in Aristotle's text, but again we run into an ambiguity concerning the apparent synonymity of phantasia and imaginatio. And it does seem especially odd that intelligible matter be explicitly equated with what he calls 'phantasible matter.' We will look more carefully at this passage below.

What we have so far seen is found in the Expositio de Anima. Beyond this, we must briefly note that Dominic makes an especially interesting elaboration of the internal senses in his better-known work, Summa Divinae Philosophiae, an extensive commentary on the Metaphysics. One point to notice is that while Dominic reiterates Thomas' distinction between the sensible forms or species received from sensation, and the intentions which are not properly sensed, he nonetheless offers a remark that the internal senses are related to each other according to their act of cognition: the exterior senses give rise to the common sense, the common sense gives rise to the phantasia (or imaginativa), the phantasia gives rise to the estimativa, and the estimativa or cogitativa gives rise to memory. ${ }^{2}$ 2

Dominicus de Flandria, In duodecim libros Metaphysicae Aristotelis, secundum expositionem [...] Angelici Doctoris, lucidissimae atque utilissimae Quaestiones 
The relation between phantasia and the estimative power is especially notable, given the common distinction between powers that are retentive and those which are receptive; phantasia is for the retention of forms received via sense, and the estimativa is for the reception precisely of intentions unsensed, following Thomas' elaboration of these capacities. Dominic seems to betray this distinction here. Beyond this, Dominic makes a particularly interesting claim concerning the reliance of the intellectual operations upon the sensitive capacities in the same article. Dominic claims that the cognition of the interior senses relies upon external sensory cognition, and that higher forms of cognition in turn rely upon internal sensory cognition. In order to cognize logical conclusions, the cognition of premises is required; and such cognition depends upon the cognition of terms or words, which relies upon the cognition of the interior senses. Dominic thus posits four kinds of cognition of the soul: sensitive, memorative, experiential, and intellective. To sensitive cognition pertain the exterior senses, while memorative and experiential cognition both belong to the interior senses, and intellective cognition belongs to the understanding. Dominic emphasizes that each latter kind of cognition

(Cologne, 1621) [reprint: Hildesheim/ Zürich/New York: Georg Olms Verlag 2010. Préface de Jean École, Leinen Series: Christian Wolff Gesammelte Werke, III. Abt.: Materialien und Dokumente, Bd. 120], Bk. I, Q. 4, a. 4, p. 27, cols. 1-2. depends upon the lower at every level. ${ }^{1}$ These are notable interpretations and elaborations Dominic has put forth concerning the internal senses: (1) the distinction between phantasia of brutes and the imagination of manimagination then being the more perfect, 'determinate' and deliberative phantasia; (2) the causal relation between external and interior senses, and then among the internal senses (but especially between phantasia and estimation); (3) the reliance of the intellectual cognition upon the internal sense capacities in general; and then (4) the four kinds of cognition, adding memorative and experiential cognition attributed to the inner senses to the more obvious types of cognition, viz., sensitive and intellective.

\section{DOMINIC OF FLANDERS ON}

\section{THE PHANTASM}

Let us return to Dominic's Expositio de Anima, to draw attention to important passages concerning the phantasm. In the proemium of the commentary the methodological questions are treated, such as the status of the science of the soul and its place within natural philosophy. Already in the proemium we find the theme of the phantasm-dictum present in some of the arguments put forth, so we might assume that, for Dominic, the notion of the phantasm indeed plays an important role in establishing the status of the science of the soul. Within the discussion of the first conclusion-viz., that the science

De Flandria, In Meta. Bk. I, Q. 4, a. 4, p. 27. cols. 1-2. 
of the soul is more noble than the other parts of natural philosophy-a doubt arises whether the science of the soul is in fact one in number. An argument to the negative posits: one single impression is not able to arise from a variety of phantasms, just as from a variety of colors a single colored thing is not able to be made, but of those things taken up in the science of the soul there are many phantasms, thus this science will not be one in number. ${ }^{1}$ This is an interesting argument. In response to this objection, Dominic argues that the analogy between the relation of colors to sight and the relation between phantasms to the intellect is not made with respect to impression, since phantasms are not the object of the intellect as colors are the object of sight. Hence while from many colors there are diverse impressions, a single science is nonetheless possible from a variety of phantasms. ${ }^{2}$ So already in the opening considerations concerning the status of the science of the soul, Dominic has understood that the familiar analogy between color and sight on the one

"Ex diversis phantasmatibus non potest fieri una impressio numero, sicut ex diversis coloribus non potest fieri una coloratio in numero, sed eorum quae traduntur in scientia de anima sunt diversa phantasmata, ergo idem quod prius," De Flandria, De Anima, proem., 60r, col. 1.

2 "Ad secundum dicendum quod non est similitudo de phantasmatibus ad intellectum, et de coloribus per respectum ad visum quantum ad impressionem, quia phantasmata non sunt obiectum intellectus, sicut colores sunt obiectum visus. Unde licet ex diversis coloribus sint diversae impressiones, tamen ex diversis phantasmatibus potest esse una scientia numero," ibid. hand, and phantasm and intellect on the other, might be insufficient if not carefully considered. The phantasm makes a second appearance within the context of the fourth conclusion in the proemium, towards the end of a long discussion concerning the many difficulties related to the science of the soul. The third doubt addressed asks whether there is some operation of the soul without the body (utrum sit aliqua operatio animae sine corpore). Et videtur quod non: firstly, so the argument runs, if there were to be some operation of the soul without the body, it would be first and foremost the understanding (intelligere), but to say that the soul understands is as if to say that it builds or weaves-this argument comes from Aristotle's text; secondly, the argument continues, to understand is never without phantasms, but phantasms are not without the body, therefore to understand is not without the body. ${ }^{3}$ This argument seems to be a strong one, stressing a clear relation or dependence of the phantasms upon the body. In response, Dominic says, following Thomas, that the soul requires the body can be understood in two ways: either as an object or an instrument, or as an object alone. Every operation of the compounded soul requires the body in one of these ways. The operations of the sensitive and vegetative soul require the body in both ways, as instrument and object, while the operations of the

"Item secundo, quia intelligere non sine phantasmatibus, ut patet in tertio huius, sed phantasmata non sunt sine corpore, Flandria, De Anima, proem., 60v, col. 2. 
intellective soul require the body only in one way-namely only as an object and not as an organic instrument. ${ }^{1}$

A final point of attention to be noted in the proemium is found in the seventh and final conclusion that is posited-viz., that the definition of natural forms and the properties of those forms necessitates that the material component be posited within the definition. A distinction is made between a definition that grasps the form alone, and a natural definition, which in turn is twofold: an imperfect natural definition that grasps only matter, and the perfect natural definition that grasps both form and matter. The following passage looks at the classification of the sciences:

"For the natural philosopher considers sensible objects as they are united to sensible matter. The mathematician, on the other hand, considers sensible objects as they are abstracted from sensible matter according to reason, though such objects are united to sensible matter in their actual existence; and while

1 “Dicendum quod operatio animae potest dupliciter indigere corpore, ut dicit hic Doctor Sanctus, vel tanquam obiecto et instrumento simul, sicut videre, audire, et huiusmodi, vel tanquam obiecto tantum. Omnes operationes animae coniunctae (quia non loquitur de separata) indigent corpore aliquo illorum modorum, non tamen indigent eo omnes utroque modo quia operationes sensitivae animae, et vegetativae indigent eo utroque modo, operationes vero animae intellectivae indigent eo altero modo tantum, videlicet tanquam obiecto et non tamquam instrumento organica. Et per hoc patet solutio ad argumenta dubii," De Flandria, De Anima, proem., 61r, col. 1. the substance that the mathematician considers is sensible in its actual existence, he does not however consider it under this aspect. The metaphysician, then, considers sensible objects insofar as they are abstracted from both sensible matter and intelligible matter, understanding the term intelligibile as phantasiabile-namely, according to what the Philosopher has named phantasia." 2

The classification of the sciences is of course common, being based upon the object of a science in relation to the levels of abstraction. Three modes of abstraction in turn produce a certain kind of definition, which demarcate the speculative sciences based upon their proper subject (obiectum), so that the parts of science are distinguished according to their differences-i.e., specific differences of the theoretical or speculative objects insofar as they are theoretical. Herein follows the distinction between different types of matter: (1) signate or determined sensible matter, (2) universal or common sensible matter, and lastly (3)

2 "Nam physicus considerat de sensibilibus secundum quod sunt coniuncta materiae sensibili. Mathematicus vero secundum quod sunt abstracta a materia sensibili secundum rationem, coniuncta tamen eis secundum esse, et licet substantia quanta, de qua considerat mathematicus, sit sensibilis secundum esse, non tamen considerat eam secundum quod huiusmodi. Metaphysicus vero considerat de praedictis secundum quod sunt abstracta tam a materia sensibili quam a materia intelligibili, accipiendo ly intelligibile, id est phantasiabile, id est secundum quod Philosophus intellectum phantasiam nominat," De Flandria, De Anima, proem., 61r, col. 2. 
intelligible matter. What is noticeable in Dominic's presentation is that he has here identified the intelligible matter of mathematics with what he calls 'materia phantasiabilis'-this seems difficult to translate. The most idiomatic expression would be something akin to imaginable matter,' though this might miss the significance. Although Thomas has famously written, phantasia sive imagination idem sunt, it could be argued that he does not use the two terms carelessly. In Dominic's text, we should understand that the significance is not simply that the objects of mathematics are somehow imaginable, or able to be conjured up-perhaps fantastically-but rather that the objects of mathematics are somehow related to phantasia, that such intelligible matter is related to phantasia. Thus, here Dominic does not say explicitly that the intelligible matter of mathematics is a phantasm, but rather that there is some relation to phantasia. Since phantasia proper seems intimately united to external sensation, there is but a small step to take to identify the mathematical objects with something like intelligible phantasms.

Thus already in the proemium we notice that there is much to consider concerning the imagination and the phantasm. We have learned that (1) the phantasms are not exactly related to the intellect as proper objects, in the way that colors are said to be the proper objects of sight; (2) that phantasms are required for understanding does not necessarily entail that the intellect requires the body for its operation (insofar as the body stands not as an object and instrument, but only as an object); and (3) there is some relation between phantasia and the intelligible matter particular to mathematics and that appropriate mode of abstractionor rather, that the objects of mathematics are 'phantasible.'

We now skip to the third book of the commentary. The final short chapter of the second treatise affirms Aristotle's well-known definition concerning phantasia: phantasia est quidam motus factus a sensu secundum actum. Attention must be drawn to one of the final points of this treatise: Dominic indicates that, according to Aristotle, phantasia sometimes contains falsity-the reason for this is that while sensation is deceived concerning the per se sensibles in very few instances, concerning the incidental objects of sense (per accidens) sensation errs often, and even moreso concerning the common sensibles; thus, Dominic continues, a fortiori phantasia is deceived concerning phantasms, since phantasia withdraws farther from the root of the cognitive power. ${ }^{1}$ It is interesting that, in this elaboration, the per accidens sensibles seem to

\footnotetext{
"Considerandum est hic secundum Philosophus quod phantasia est aliquando falsorum, cuius ratio est quia sensus, licet circa proprium sensibile ut in paucioribus decipiatur, tamen circa sensibilia per accidens decipitur, non ut in paucioribus sed ut saepe, et magis circa sensibilia communia, ergo a fortiori phantasia circa phantasmata decipitur cum magis recedat a radice virtutis cognoscitivae," De Flandria, De Anima III, tr. 2, cap. $3,79 v$, col. 2.
} 
occupy a middle ground here between proper sense objects and the common sensibles, since both are, for Dominic as for Thomas, two kinds of per se objects of sense. That the sensitive power would have a tendency to err more concerning common sensibles rather than the incidental objects of sense seems to run inconsistent with what he had previously articulated. However, the point we would rather like to emphasize is the arrangement between phantasia and phantasms implied by Dominic's conclusionphantasia circa phantasmata. Proper and common sensibles are both per se objects of sensation so far as they make an impression upon the senses, ${ }^{1}$ so the conclusion implies that phantasms are related to the phantasia as proper objects. This is significant. Prima facie it would seem that phantasms would indeed be the objects of the imagination (and this may very well be the case for Aristotle); however, if we are concerned to treat Dominic as a reader of Thomas, then we should note that-so far as we are aware-Thomas never explicitly states that phantasms are the objects (and certainly not the proper objects) of phantasia.

1 Cf. ST Ia, 78, 3, ad. 2; Dominic follows Thomas on this point: "differentia sensibilium sumenda est secundum differentiam immutationis. Vel ergo tale sensibile nihil facit ad immutationem sensus, vel aliquid facit. Si primum, sic est sensibile per accidens. Si secundum, sic est sensibile per se, et hoc est dupliciter, vel quia immutatio attenditur quantum ad speciem agentem, sic est sensibile per se proprium, vel quantum ad modum actionis, sic est sensibile per se commune," De Flandria, De Anima II, tr. 2, cap. 7, 74v, col. 1-2.
If we continue, we find a threefold elaboration of the agent intellect in Book III. The operation of the agent intellect is threefold insofar as: first, the agent intellect illuminates phantasms; second, it abstracts intelligible species from those illuminated phantasms; third, it gives determination to the possible intellect with an abstracted intelligible species, the possible intellect itself being indeterminate. It might be argued, Dominic offers, that the agent intellect does not impress something in the phantasms, therefore it does not illuminate. Dominic responds that the agent intellect does not illuminate phantasms by impressing something upon phantasms, but rather by a process of abstraction, and by strengthening the intellect for the reception of intelligible species. ${ }^{2}$ Regarding the reliance of the intellect on the phantasms, Dominic affirms Aristotle's claim: the intellect is not able to understand except through phantasms. This is proved since just as sense has a relation to the sensible object as sight to color, so in this way does the intellect have a relation to phantasms; but sensation is not able

\footnotetext{
“intellectus agentis triplex est operatio. Prima est illustrare phantasmata. Secunda est ex phantasmatibus illustratis speciem intelligibilem abstrahere. Tertia est per speciem intelligibilem abstractam intellectum possibilem determinare, qui est secundum se indeterminatus. Et dum dicebatur, intellectus agens non imprimit aliquid in phantasmatibus, ergo non illuminat. Dicendum quod non illuminat phantasmata aliquid imprimendo phantasmatibus, sed magis abstrahendo et confortando intellectum possibilem ad susceptionem specierum intelligibilium," De Flandria, De Anima III, tr. 3, cap. 4, 81v, col. 2.
} 
to sense without sensible objects (sight is unable to see without color), therefore the intellect is not able to understand without phantasms, namely by turning itself towards phantasms. It is inferred then that it is necessary for understanding to behold phantasms. ${ }^{1}$ Dominic does concede, however, that thinking through phantasms is the proper operation of the intellect in its current, embodied state, and not the proper operation of the intellect in an absolute consideration. ${ }^{2}$

Dominic presents the following objection: the intellect understands the mathematical objects, which are abstracted from matter; therefore the intellect does not always require the phantasms. In response to this objection, Dominic answers that although the mathematical objects are abstracted from sensible matter (from both common or universal sensible matter as well as individuated matter), the mathematical objects are not however abstracted from intelligible matter-that is, again, materia phantasiabilis. We recall that we have

"Intellectus non potest intelligere nisi per phantasmata. Haec conclusio probatur tali ratione. Nam sicut se habet sensus ad sensibile et visus ad colorem, ita se habet intellectus ad phantasmata, sed sensus non potest sentire sine sensibili, neque visus potest videre sine colore, ergo intellectus non potest intelligere sine phantasmatibus, videlicet convertendo se ad phantasmata. Ex quo infertur quod necesse est intelligentem phantasmata speculari," De Flandria, De Anima III, tr. 3, cap. 6, 82v, col. 1.

2 "intelligere per phantasmata est propria operatio intellectus coniuncti secundum quod huiusmodi, non autem ipsius intellectus absolute considerati," De Flandria, De Anima III, tr. 3, cap. 4, 82r, col. 1. already seen this in the proemium. While Thomas does often refer to the mathematical objects in his De Anima commentary, he himself does not make this claim regarding the intelligible matter as phantasiabilis.

Regarding the necessity of the phantasm, Dominic later offers an equally important objection: it is doubted whether the intellect understands by abstracting from phantasms. Four objections are given, which we will treat individually with their corresponding responses. First, and interestingly, it is argued that the intellect does not understand by abstracting from phantasms since, in understanding, the intellect converts or turns itself towards phantasms. It is answered that the intellect indeed always understands by converting or turning itself towards phantasms, and also by abstracting-it turns towards phantasms insofar as it understands the universal which has existence in singulars, and it abstracts insofar as it understands the universal while not considering the singular. ${ }^{3}$ Secondly: it appears as if the intellect does not need to turn towards phantasms since just as

3

“Dubitatur secundo, utrum intellectus intelligat per abstractionem a phantasmatibus, et videtur quod non. Nam intellectus intelligendo convertit se ad phantasmata, ergo intellectus non intelligit abstrahendo a phantasmatibus [...] Ad primum dicendum quod intellectus intelligit semper convertendo se ad phantasmata, et etiam abstrahendo, convertendo quidem inquantum intelligit universale, quod habet esse in singularibus, abstrahendo vero inquantum intelligit universale non intelligendo singulare," De Flandria, De Anima III, tr. 3, cap. 6, 83r, col. 1. 
sight has a relation to color, so too does intellect have a relation to phantasms, but sight is not able to see color by abstracting from color, therefore the intellect is not able to understand by abstracting from phantasms. So here again arises the analogy between color and sight on the one hand and phantasm and the intellect, and the objection again presses on the way in which the analogy limps. In response, Dominic claims precisely that the likeness or similitude between the relation of color and sight and the phantasms with respect to the intellect does not hold in every respect, for color according to its nature is visible, but the phantasms in themselves (secundum se) are not intelligible objects (non sunt intelligibilia), and therefore they require the power of the agent intellect, and hence those relations are not exactly similar. ${ }^{1}$

The third objection holds that nothing is able to be understood without that which belongs to the definition of the thing, but matter precisely falls under the definition of a natural thing, therefore the intellect will not be able

1 "Sicut se habet visus ad colorem, ita se habet intellectus ad phantasmata, ut concessum est: sed visus non potest videre colorem abstrahendo a colore, ergo intellectus non potest intelligere abstrahendo a phantasmatibus [...] Ad secundum dicendum quod non est omnimoda similitudo inter colorem per respectum ad visum et inter phantasmata per respectum ad intellectum. Nam color secundum sui naturam est per se visibilis, sed phantasmata secundum se non sunt intelligibilia, et propterea requiritur virtus intellectus agentis, ut supra declaratum est, unde non est simile," De Flandria, De Anima III, tr. 3, cap. 6, 83r, col. 1. to understand natural things without matter, therefore it follows that the intellect cannot understand without the individual conditions of matter, and thus does not abstract from phantasms. In response to this, Dominic makes the distinction between determinate or signate matter and common or universal matter: signate matter is indeed the principle of individuation, however common matter is not, and it is common matter that is placed in the definition of natural things. This of course recalls the division of the sciences, with physics having its corresponding object in those forms separated from their individuated signate matter, but nevertheless including common matter. ${ }^{2}$ The fourth and final objection argues that if we are to hold that the intellect in understanding abstracts from phantasms, either that abstraction belongs to the possible intellect or to the agent intellect; it cannot belong to the possible intellect, since it is receptive and passive, but neither can it belong to the agent intellect, since the agent intellect illuminates phantasms, and consequently it belongs to something that makes an impression rather than something that abstracts. The response affirms that to abstract from phantasms
"Nihil potest intelligi sine illo quod cadit in definitione rei, sed materia cadit in definitione rei naturalis, ergo intellectus non potest intelligere res naturales sine materia. Sed materia est principium individuationis, ergo sequitur quod intellectus non potest intelligere absque conditionibus individuantibus, et sic non abstrahit se a phantasmatibus [...] Ad tertium dicendum quod materia signata est principium individuationis, non autem materia communis, quae ponitur in diffinitione rei naturalis," ibid. 
belongs to the agent intellect, insofar as phantasms are made more suitableon account of the proximity they have to the agent intellect-since from them the agent intellect is able to abstract the intelligible species to be presented to the possible intellect. ${ }^{1}$

\section{CONCLUDING REMARKS}

In this study we have tried to focus upon the theme of the imagination and phantasm, which provides a useful angle of analysis, a window through which we can take up the issues related to sensitive and intellectual cognitionand, more broadly, topics concerning the human soul-as we find them in Medieval and Renaissance scholastic thinkers. We have taken up Dominic of Flanders as a $15^{\text {th }}$ century reader of Thomas Aquinas. In order to judge Dominic's claims-and in order to pass a judgment on his fidelity to his confrère-however, we have claimed that it is helpful to refrain from a static understanding of Thomas, and rather to exaggerate potential difficulties in

“Praeterea. Si intellectus intelligendo abstraheret a phantasmatibus, vel ergo abstrahere pertinet ad intellectum possibilem, vel ad intellectum agentem. Non ad intellectum possibilem, cum eius sit recipere, nec ad intellectum agentem, cum eius sit phantasmata illustrare. Et per consequens magis in eis aliquid imprimere quam abstrahere [...] Ad quartum dicendum quod abstrahere a phantasmatibus pertinet ad intellectum agentem, inquantum ipsa (propter propinquitatem quam habent ad ipsum) efficiuntur habilia ut ab ipsis possit abstrahi species intelligibilis praesentanda intellectui possibili," De Flandria, De Anima III, tr. 3, cap. 6, 83r, col. 1 . order to create a suitable contrast. Dominic's Expositio super libros De Anima demonstrates a spirit of fidelity to 'Holy Thomas,' his preferred epithet. This commentary over the De Anima was meant to distill Aquinas' teaching into summary form, and, whatever Dominic's intentions concerning its posterity, the work was indeed employed by printers of the following centuries as a kind of compendium to Thomas' own commentary. This work, then, should be seen as a Thomistic commentary on the De Anima, and should serve as a valuable gauge to measure the character of the Thomism of the $15^{\text {th }}$ century. While Dominic would claim no originality, and neither explicitly corrects Thomas nor highlights tenuous points, Dominic nonetheless elaborates a unique interpretation of the phantasm. If modern-day readers tend to veer to the side of materiality in conceiving of the phantasm, understanding the phantasm as a sense-image or sense-data and the like, then Dominic, recalling the degrees of 'materiality,' would veer to the side of intelligibility in his conception of the phantasm, claiming the intelligible matter of mathematics to be something like 'phantasmal matter.' He is more explicit about distinguishing between a phantasia proper to brute animals, and a more perfect, determinate imagination that he even labels as 'rational.' Dominic's attempt to render lucid Thomas' discussion over these concepts has allowed for something of an intellectualizing of the phantasm, and an elevation of phantasia over and beyond the task of retaining sensible 
forms. In order to offer a fuller picture of Dominic, more detailed research is required concerning his intermediate sources. Dominic's citations in this commentary are rather sparse; however, notably absent is any explicit mention of his former teacher at Paris, Jean Letourneur (Versoris), upon whose commentary over the De Anima Dominic relies heavily.

One final methodological caveat must be pointed out: the problem pressed upon here-viz., the ontological status of the phantasm-seems to be neither a Medieval nor a Renaissance problem. What do we mean by this? We mean, more specifically, that it was not an explicit problem for Thomas, and does not arise for Dominic in the form of a question or precise problem. That is, nowhere in Thomas' writings-so far as the present author is aware-do we find a question dedicated specifically to the phantasm qua phantasm. The treatments of such topics, especially as they are found in the Summa, occur as preambles to a consideration of the intellect. "A theologian," Thomas says of his proper task, "must be concerned specifically only with the intellective and appetitive potencies, in which the virtues are found. But since the understanding of these capacities depends in a way upon the others, $[\ldots]$ those powers that come before the intellect must be taken up first"-that is to say, the sensitive powers. ${ }^{1}$ So it is that for someone like

1 “Ad considerationem autem theologi pertinet inquirere specialiter solum de potentiis intellectis et appetitivis, in quibus virtutes inveniuntur. Sed quia cognitio harum potentiarum quodammodo
Thomas, treatment of the sensitive potencies, of the imagination, is rather incidental and not for its own sake, especially as found in his Summa. While Dominic might offer peculiar and interesting elaborations concerning the phantasma, it does not arise as a problem in and of itself. Thus it may be that the attention given to this problem here reflects a fundamental difficulty in understanding such a theoretical concept, and may very well import foreign concerns; a further difficulty is added when we notice that such termsphantasma, imago, similitudo-though intended with technical precision in such accounts of the soul and intellect, cannot but remain vague, and not only for us, but in the common parlance of the Middle Ages and Renaissance as well. Thus, this current study perhaps serves as a broader reflection of the difficulty we constantly face in trying to understand these notions removed from us by centuries, and then in reformulating them in our own philosophical language.

dependet ex aliis, ideo nostra consideratio de potentiis animae in speciali erit tripartita, primo namque considerandum est de his quae sunt praeambula ad intellectum; secundo, de potentiis intellectivis; tertio, de potentiis appetitivis." ST Ia, 78, pro. [250]. 


\section{BIBLIOGRAPHY}

Aquinas, T. (1889). Opera omnia, vol. 5: Pars Prima Summae Theologiae, a quaestione $L$ ad quaestionem CXIX. Roma: Typographia Polyglotta.

Aquinas, T. (1959). In Aristotelis Librum de Anima Commentarium (ed. A. M. Pirotta). Torino: Marietti.

Aquinas, T. (1984). Opera omnia, vol. 45,1: Sententia libri de Anima. Roma; Paris: Commissio Leonina.

Fabro, C. (1938). "Knowledge and Perception in Aristotelic-Thomistic Psychology". New Scholasticism, 12, pp. 337-365.

Ficino, M. (2005). Platonic Theology, v. 5: Books 15-16 (ed. J. Hankins, W. Bowen; trans. M. J. B. Allen). Cambridge; London: Harvard University Press.

Flandria, D. de, (1550). Divi Thomae Aquinatis in tres libros de Anima [...] Accedunt adhaec acustissime Quaestiones Magistri Dominici de Flandria [...]. Venetiis: Hieronymum Scotum.
Flandria, D. de, (1621). In duodecim libros Metaphysicae Aristotelis, secundum expositionem [...] Angelici Doctoris, lucidissimae atque utilissimae Quaestiones. Köln [reprint: Hildesheim; Zürich; New York: Georg Olms Verlag, 2010. Préface de Jean École, Leinen Series: Christian Wolff Gesammelte Werke, III. Abt.: Materialien und Dokumente, Bd. 120].

Frede, D. (2001). "Aquinas on Phantasia". In: D. Perler (ed.), Ancient and Medieval Theories of Intentionality. Leiden; Boston; Köln: Brill, pp. 155-184.

Kaeppeli, T. (1970). Scriptores Praedicatorum Medii Aevi, Vol. 1. Roma: S. Sabina.

Kretzmann, N. (1993). "Philosophy of Mind". In: N. Kreztmann, E. Stump (eds.), The Cambridge Companion to Aquinas. Cambridge University Press, pp. 128-159. 
Lonergan, B. (1992). Insight: A Study of Human Understanding (ed. F. E. Crowe, R. M. Doran). Toronto: University of Toronto Press [originally published by Longmans, Green, London 1957].

Lonergan, B. (1997). Verbum: Word and Idea in Aquinas. Toronto: University of Toronto Press [originally published as a series of articles in Theological Studies, 1946-1949].

Pomponazzi, P. (1948). On the Immortality of the Soul. In: E. Cassirer et al. (eds.), The Renaissance Philosophy. London: University of Chicago Press, pp. 280381.

Suárez, F. (1861). Opera Omnia tomus tertius [...] Tractatus tertius de Anima. Paris: Vives. 